\title{
EFFECT OF THE QUALITY OF FERMENTED COFFEE WITH THE ADDITION OF SUGARS
}

\author{
Daniel Gonçalves Siqueira ${ }^{1}$, Kleso Silva Franco Junior ${ }^{2}$, Rodrigo Pereira Mariano ${ }^{3}$, \\ Giselle Prado Brigante ${ }^{4}$, Marcio de Souza Dias ${ }^{5}$ \\ ${ }^{1,3}$ Academic of the CESEP agronomy course. \\ Higher education and research center of MACHADO MG. \\ ${ }^{2}$ Teacher/Doctor, Faculty of agronomy CESEP. \\ Higher education and research center of MACHADO MG. \\ ${ }^{4}$ Teacher/Doctor/coordinator of the faculty of agronomy CESEP. \\ Higher education and research center of MACHADO MG. \\ ${ }^{5}$ Teacher/doctor, Secretary of Education of the State of MG.
}

DOI: https://doi.org/10.51193/IJAER.2020.6507

\begin{abstract}
With the growing demand of the market in relation to the quality of coffee, the producer has increasingly sought to improve his cultivation techniques, pre and post-harvest in order to achieve better results. The current coffee culture is undergoing great changes in all sectors and there would be no difference in the quality of drink, quality of grains, different aromas, among others. Among the techniques used to improve the product and add more value to coffee, there is the fermentation process, which has been delivering good results for special coffee producers. The research was carried out at the Limeirinha site in the city of Machado, south of Minas Gerais, in the year 2020, with the cultivar of the new world coffee, in a completely randomized design with 7 treatments with 4 replications totaling 28 parcels, 1 of which was a control without the addition of sugars and without fermentation, and 6 treatments submitted to controlled anaerobic fermentation and 5 of these with added brown sugar, honey, molasses and cane juice diluted in $100 \mathrm{~mL}$ of water added to 2 liters of coffee (grain) per $\mathrm{m}^{2}$ and stored in gallons 5 liters with closure simulating airlock valve. Where quality was assessed according to the SCAA methodology. It is concluded that the addition of sugar did not provide quality improvement, according to notes from the SCAA methodology.
\end{abstract}

Keywords: Anaerobic, Fermentation, SCAA. 
International Journal of Agriculture and Environmental Research

ISSN: 2455-6939

Volume: 06, Issue: 05 "September-October 2020"

\section{INTRODUCTION}

Brazil is the largest producer and exporter of coffee in the world, the fruit that today is responsible for the income of more than 8 million people, arrived in the country in 1727, through Belém do Pará, coming from French Guiana and being brought by Sergeant- M or Francisco e Mello Palheta, according to data from the Ministry of Agriculture, Livestock and Supply MAPA (2018).

Productivity in coffee production was one of the forms of expression of agricultural research, and until the 1960s, it was practically the only indicator of economic and commercial efficiency for coffee production, however, quality would also need to be studied, understood and incorporated in this system. Evaluation (SILVA \& CORTEZ 1998).

In Brazil, the quality of coffee is measured according to two classifications, one based on physical characteristics (Type), through its aspect and purity, and the other, by the aroma of the drink, which is considered the most important, since it is refers to the organoleptic characteristics of the drink (CARVALHO et al., 1994).

The chemical composition of the grains, determined by genetic, environmental and cultural factors, as well as the methods of harvesting, processing and storage are important factors, as they directly affect the quality of the drink (FERREIRA, 2017).

After harvesting, drying represents the phase of greatest risk of loss of coffee quality, involving a series of important procedures, but easy to perform, provided that there is a minimum infrastructure and skilled labor (MESQUITA et al., 2016).

Fermentation is a biological process in which sugars are converted into cellular energy, and when used in coffee it can be aerobic with the presence of oxygen and anaerobic that does not need oxygen, If done incorrectly for longer than necessary can reduce the quality of coffee compromising attributes such as body, sweetness and acidity (MUINHOS, 2019).

The Sprounting Process or Semi-carbonated Maceration created by barista Léo Moço is made in plastic drums with Airlock valves generating an anaerobic environment, due to the presence of $\mathrm{CO}_{2}$ the development of bacteria and fungi is inhibited causing the enzymes in the coffee husk to promote a natural fermentation adding much more flavor and aroma to the beans. It is considered semi-carbonic, because at the beginning of the process there is a small amount of oxygen present, as the fermentation produces $\mathrm{CO}_{2}$, oxygen is slowly being eliminated, making the process strictly anaerobic (SOUZA, 2020). 
International Journal of Agriculture and Environmental Research

ISSN: $2455-6939$

Volume: 06, Issue: 05 "September-October 2020"

Good quality coffee is one that has a drink with a good aroma, good body, good acidity and smoothness, homogeneous color and appearance. In addition, it should not contain green, dark green, black-green, burnt and black defects (CARVALHO JÚNIOR etal., 2003).

The coffee is fermented to facilitate the removal of the mucilage layer that surrounds the bean and adheres to it. There are generic differences that affect the sensory attributes of processed coffee "wet" or "dry", both required by different market segments: the first have a milder flavor, with less body and high acidity, while the natural "arabica" they have more body and astringency and less acidity (CHALFOUN \& FERNANDES, 2013).

Sugar releases carbondioxide faster than starch. Sugar is consumed by yeast and fermentation products contribute to the taste, volume, aroma and color of the final product (AI-Additives Ingredients).

According to the SCAA methodology (2015), the classification given by the flavor in the cuptasting can present characteristics such as: soft drink, extremely soft drink and only soft drink, hard drink, riada drink, rio drink and rio zone drink. The attributes that are evaluated in this method are: Fragrance / aroma, uniformity, absence of defects (clean cup), sweetness, flavor, acidity, body, finish, balance, defects and overall evaluation.

The objective of this work was to evaluate the effects of using sugar-based additives in improving the quality of coffee.

\section{MATERIAL AND METHODS}

The experiment was carried out at the Limeirinha site in the city of Machado Minas Gerais, located at latitude $21^{\circ} 43^{\prime} 56^{\prime \prime} \mathrm{S}$ and longitude $45^{\circ} 54^{\prime} 30^{\prime \prime} \mathrm{O}$ and altitude of 830 meters above sea level. real time, warm temperate climate, maximum temperature of $20{ }^{\circ} \mathrm{C}$ and minimum $14,7^{\circ} \mathrm{C}$ with anaverage of $23,4{ }^{\circ} \mathrm{C}$.

The chosen plot was (plot 1 / stone), with the cultivar Mundo Novo about 20 years old, the same being a 4-year-old sprout, 3m x 1m spacing, the grains of the upper third harvested with a manual rake were selected harvested, a selection of the cherry grains was made and subjected to the brix grade test, with an average of $18^{\circ}$.

It was made in a space of approximately $30 \mathrm{~m}^{2}$ concrete for the drought to take place, together with a covered area for rainy days. For the installation of the study, the following materials were used: 24 gallons of 5 liters each, 24 PET bottles of 2 liters, 10 meters of transparent transparenthose. Each experimental parcel soon after wards the lids were sealed with hot glue, at the end water was placed in all pet bottles. This hose scheme will be simulating the same 
International Journal of Agriculture and Environmental Research

ISSN: $2455-6939$

Volume: 06, Issue: 05 "September-October 2020"

function as the Air lock valves, which have the function of sealing the gallons, preventing oxygen from entering during fermentation.

The experiment was conducted in a completely randomized design with 7 treatments and 4 repetitions totaling 28 parcels, where the coffee was submitted to the following treatments: 1Control without added sugars and without fermentation, treatment 2- addition of Rapadura (118 $\mathrm{g})$, treatment 3- addition of sugar (100 g), treatment 4- addition of Honey (122 g), treatment 5addition of molasses (140 g), treatment 6- addition of Cane juice (182 g), treatment 7- control with fermentation without added sugars, 2 liters of coffee per $\mathrm{m}^{2}$ were used to add these additives, in the case of the solids they were dissolved in a syrup with $(100 \mathrm{~mL})$ of water and the liquids were added directly, at the moment it was filling the gallons with coffee, additives were added little by little and mixing until completely filled, after filling all the portions were covered and sealed with glue and taken to an airy place that has the presence of sunlight.

The dosage used in the treatments were:

- 1 Witness without fermentation and without added sugars;

- Treatment 2 with the addition of Rapadura (118g) diluted in $100 \mathrm{~mL}$ of water;

- Treatment 3 with added Sugar $(100 \mathrm{~g})$ diluted in $100 \mathrm{~mL}$ of water;

- Treatment 4 with the addition of Honey (122g) diluted in $100 \mathrm{~mL}$ of water;

- Treatment 5 with the addition of molasses $(140 \mathrm{~g})$ diluted in $100 \mathrm{~mL}$ of water;

- Treatment 6 with the addition of sugarcane juice $(182 \mathrm{~g})$ diluted in $100 \mathrm{~mL}$ of water;

- Fermented treatment 7, with no added sugars.

After the fermentation time has passed, which is on average 3 or 4 days, after visualizing that the $\mathrm{CO}_{2}$ emission in the home made airlock valve has ceased, the coffee was removed from the gallons and taken to a concrete terrace to start the drying process, each treatment was dried separately, to facilitate drying and for a more dry to occur, the coffee was stored everyday so that it did not have contact with dew and in the morning it was spread. The drying process took 18 days to reach $11,5 \%$ humidity, after which the coffee was processed and sent for evaluation of the drink quality according to SCAA methodology (2015). The cultivar used was Mundo Novo, coffee attributes were evaluated according to the SCAA methodology (2015), also having other parameters evaluated as well as the yield in $\mathrm{Kg}$ and drying time hours.

The data obtained with the evaluations were submitted to statistical analysis using the SISVAR® software (FERREIRA, 2014), the significant difference between treatments being determined by the F test, with the means compared by the Scott-Knott test atthe 5\% probability level. 


\section{RESULTS AND DISCUSSION}

After processing the coffee, they were sent to 4 tasters, three in Machado and another in Poço Fundo, after tasting they were subjected to the statistical analysis test using the SISVAR ${ }^{\circledR}$ software (FERREIRA, 2014).

Treatment 7 Control with fermentation without addition of additives was the one that presented the best result among the others, with 82,5 as a score, followed by treatments 1,3 and 6 , where treatment 1 is the Control without fermentation with a score of 79, 5, Treatment 3 with Sugar Addition with note 80 and Treatment 6 with Sugar Cane Addition with note 79, had the same statistical results, but treatment 3 had the highest score in SCAA (2015), followed by treatments 2, 4 and 5 which are Treatment 2 Addition of Rapadura with note 78,5, Treatment 4 Addition of Honey with note 76 and Treatment 5 Addition of molasses with note 78, which obtained the lowest scores.

\section{Graph 1- SCAA}

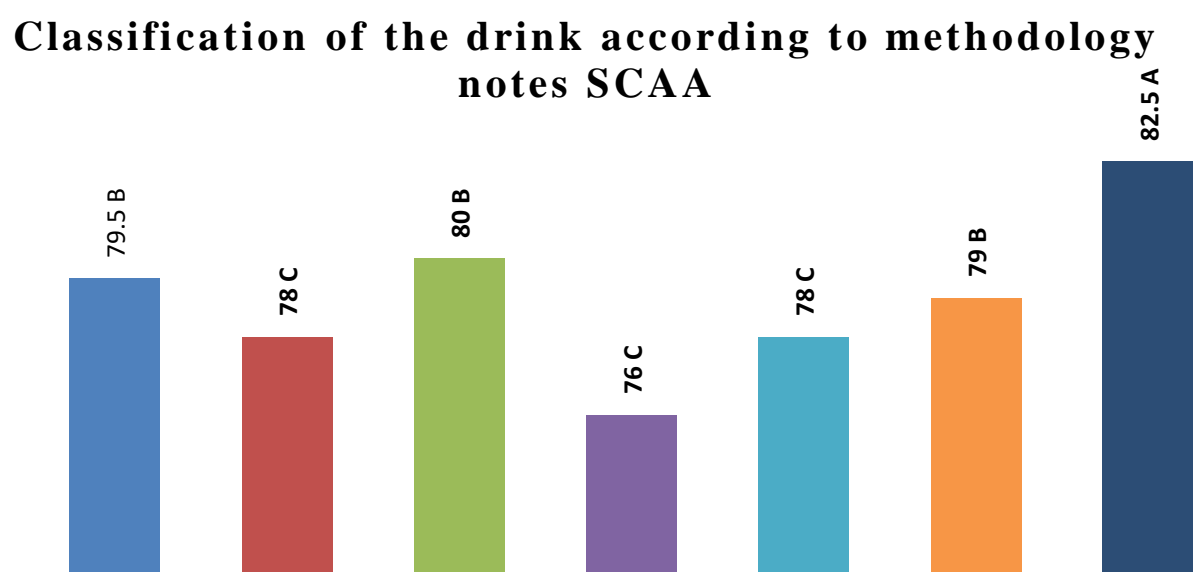

- Treament 1 Witness without fermentation and without added sugars;

Treatment 2 fermentation with the addition of Rapadura

Treatment 3 fermentation with added Sugar

Treatment 4 fermentation with the addition of Honey

Treatment 5 with the addition of molasses

$\square$ Treatment 6 fermentation with the addition of sugarcane juice

Treatment 7, fermentation with no added sugars 
Notes. * Means followed by the same letters do not differ statistically from each other by the Scott-Knott test at $5 \%$ probability.

According to Araújo (2018), fermentation has the potential to confer other sensory characteristics to the coffee drink, which can modify its acidity, but, remembering that for a better fermentation process, balanced temperature and humidity are required for the yeasts to act more efficiency.

Silvestre (2019) says that the addition of exogenous components such as sugars accelerates the coffee fermentation process, and can even improve the sensory characteristics of the fruit, and present an improvement in the body and fragrance of the drink according to notes from the SCAA protocol (2015) of sensorial analysis by the cup test, however the same fermentation process done without adding additives, but for the correct period of time and favorable climatic conditions results in a better sensory quality.

What can be compared to the work presented, since the best final score in the sensory evaluation according to the methodology established by SCAA (2015) was with treatment 7, the control with fermentation without the addition of additives, which obtained the best result with a higher score the 80 points that are necessary to be considered a special coffee.

According to the SCAA methodology (2015), the "Total Result" is initially calculated, which is the sum of the evaluations of each attribute, then the value corresponding to the defects is subtracted, thus obtaining the "Final Result". This Results Key has been shown to be efficient in describing the quality of the coffee from the Final Result of its sensory evaluation.

Graph 2 shows the results from aromas acquired through fermentation tests, aromas of sweetness, caramel, sour, red fruits and yellow fruits were detected, treatments 7, 6, 4, 3 and 2 obtained sweet aromas, treatment 1 caramel aroma was detected, treatments 3 and 2 a little sour, treatment 6 red fruits and treatment 7 yellow fruits. 


\section{Graph 2- Aromas}

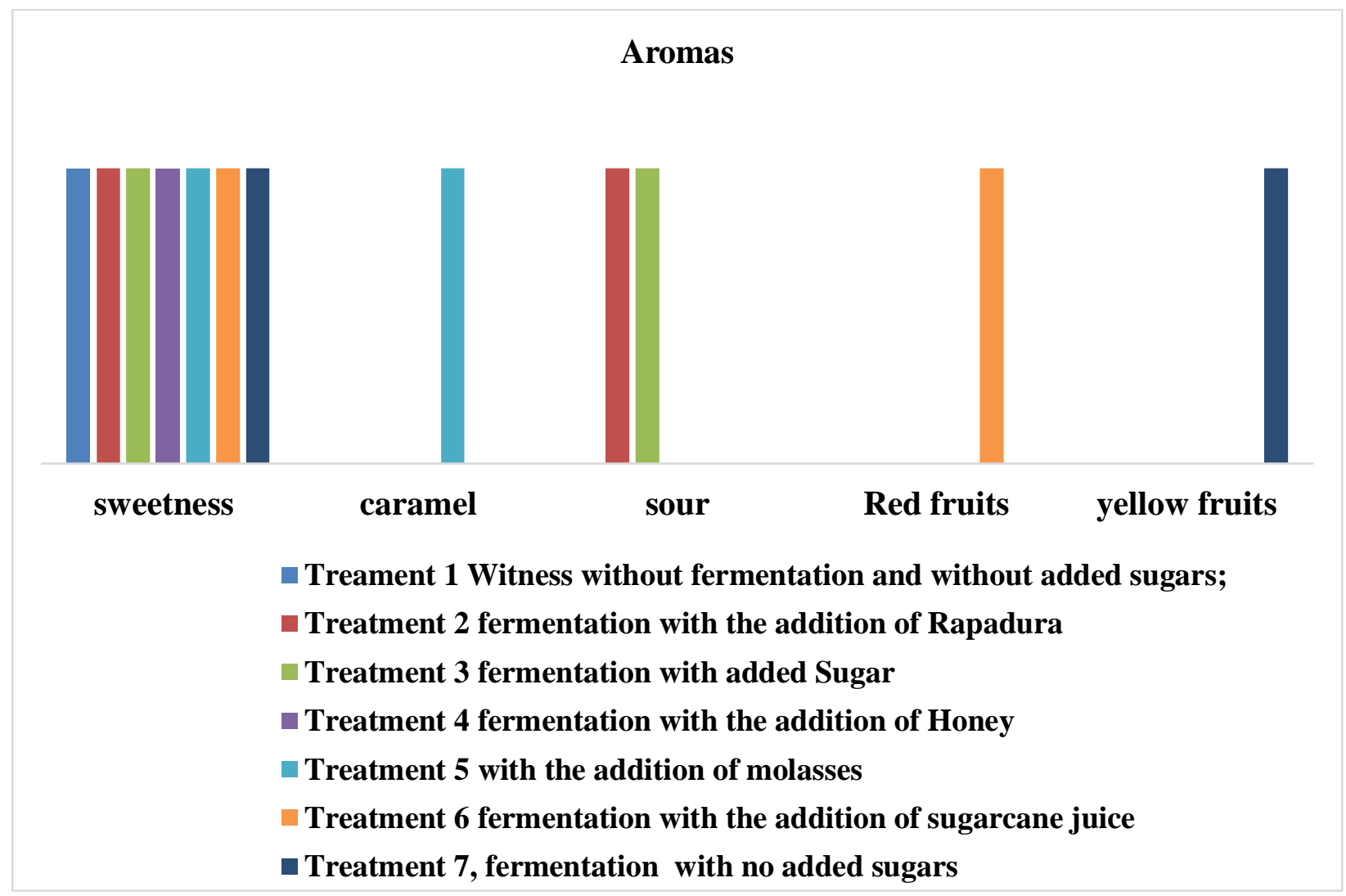

*Means followed by the same letters do not differ statistically from each other by the Scott-Knott test at $5 \%$ probability.

In relation to the classification according to SCAA methodology (2015), for special coffees the results presented in relation to the attributes are sweetness, acidity (low and medium), aroma of red, purple and yellow fruits, little sour and little caramel, found in the sensory evaluation.

According to Rodrigues etal. (2017), a desired fermentation, when well controlled, always generates benefits to the quality of the coffee drink, including being able to obtain special products.

Pereira et al. (2020) mentions that the anaerobic fermentation methodology with water, peeled and submerged coffees, controlled by time, temperature and humidity, show that the coffee that did not have the water obtained better result than the one that had the presence of fermentation, and that the drying time and temperature directly influence the quality of the coffee drink. 
Volume: 06, Issue: 05 "September-October 2020"

Santos et al. (2020) emphasizes the importance of the coffee drying process and the correct time for obtaining quality coffees, as well as the pre- and post-harvest treatments can influence the flavor and aroma characteristics of the coffee drink.

Table 1 shows the classification of coffee by sieve, bottom and pick, treatments 2 (addition of brown sugar and anaerobic fermentation), 3 (addition of sugar and anaerobic fermentation), 4 (addition of honey and anaerobic fermentation), 5 (addition molasses and anaerobic fermentation), 6 (addition of sugarcane juice and anaerobic fermentation), and 7 (anaerobic fermentation, without addition of sugars) did not differ statically in the $16(\%)$ sieve with an average of $59,6 \%$, only the treatment 1 (control without fermentation) had a difference with $55 \%$ of average.

Followed by the results by background, all treatments had no statistical difference with an average of $4,14 \%$ of background.

Finally it shows the picking, treatments 3 (addition of sugar and anaerobic fermentation), 5 (addition of molasses and anaerobic fermentation) and 6 (addition of sugarcane juice and anaerobic fermentation) did not have statistical differences at the level of collection with average of 16,3\%, depending on treatments 1 (control without fermentation), 2 (addition of rapadura and anaerobic fermentation), 4 (addition of honey and anaerobic fermentation), and 7 (anaerobic fermentation without addition of sugars) with an average of $12,5 \%$.

Table 1: Classification of coffee by sieve, bottom and collection (\%)

Treaments

Bottom Picking

Sieve

16 above

Treament 1 Witness without fermentation and without added sugars;

$55 \mathrm{~B} \quad 3 \mathrm{~A} \quad 12 \mathrm{~B}$

Treatment 2 fermentation with the addition of Rapadura

$59 \mathrm{~A}$

$4 \mathrm{~A}$

$12 \mathrm{~B}$

Treatment 3 fermentation with added Sugar

$60 \mathrm{~A}$

$3 \mathrm{~A}$

$16 \mathrm{~A}$

Treatment 4 fermentation with the addition of Honey

$61 \mathrm{~A}$

$3 \mathrm{~A}$

$13 \mathrm{~B}$

Treatment 5 with the addition of molasses

$59 \mathrm{~A}$

$4 \mathrm{~A}$

$15 \mathrm{~A}$

Treatment 6 fermentation with the addition of sugarcane juice

$58 \mathrm{~A}$

$4 \mathrm{~A}$

$18 \mathrm{~A}$

Treatment 7 , fermentation with no added sugars

$61 \mathrm{~A}$

$4 \mathrm{~A}$

$13 \mathrm{~B}$

* Means followed by the same letters do not differ statistically from each other by the ScottKnott test at $5 \%$ probability. 
International Journal of Agriculture and Environmental Research

ISSN: 2455-6939

Volume: 06, Issue: 05 "September-October 2020"

In Brazil, the quality of coffee is evaluated, mainly, according to two classifications: by type and by drink. The classification by type investigates the quality of the coffee with regard to the physical aspect of the beans, whether or not there are defects and impurities. The classification of the drink itself involves all factors related to the taste, taste, flavor, aroma or smell of the coffee when it goes through the roasting process. There is also a classification by sieve that analyzes the grain size that can be larger or smaller, and classified from twelve to twenty. (PIRES \& CUNHA, 2018).

\section{CONCLUSION}

It is concluded that the addition of sugar did not provide quality improvement, according to notes from the SCAA methodology (2015).

\section{REFERENCES}

ARAÚJO, G. A. de F. Novos procedimentos de fermentação para potencializar o perfil sensorial dos cafés obtidos no município de Coromandel, MG. 2018. Disponível em: <http://www.unicerp.edu.br/ensino/cursos/cafeicultura/monografias/2018/NOVOSP R OCESSOSDEFERMENTACAO.pdf $>$. Acesso em: 30 set. 2020.

CARVALHO JÚNIOR, et al. Influência de diferentes sistemas de colheita na qualidade de café (Coffea arábica L.). Ciência e Agrotecnologia. V.27. n.5. Lavras. Out. 2003.

CARVALHO, V, D, de et al. Relação entre a composição físico-química e química do grão beneficiado e a qualidade de bebida do café. Atividades de polifenoloxidase e peroxidase, índice de coloração de acidez. Pesquisa Agropecuária brasileira. Brasília, v.29, n.3, p. 449-454, mar. 1994.

CHALFOUN, S. M; FERNANDES, A. P. Efeitos da fermentação na qualidade da bebida do café. $2013 . \quad$ Disponível em:< https://www.esalq.usp.br/visaoagricola/sites/default/files/va12-qualidadedabebida01.pdf >. Acesso em: 09 set. 2020.

Evolução do Açúcar. AI- Aditivos Ingredientes. Disponível em: < https://aditivosingredientes.com.br/artigos/todos/a-evolucao-doacucar\#: :text=O\%20a\%C3\%A7\%C3\%BAcar\%20libera\%20di\%C3\%B3xido\%20de,este ndendo\%20sua\%20vida\%20de\%20prateleira. Acesso em: 29 set. 2020.

FERREIRA, D. F. Sisvar: a computer statistical analysis system. Ciência e Agrotecnologia, Lavras, v. 35, n. 6, p. 1039- 1042, 2011. 
International Journal of Agriculture and Environmental Research

ISSN: 2455-6939

Volume: 06, Issue: 05 "September-October 2020"

FERREIRA, W.P.M. Qualidade do café em MG é influenciado pelas características locais. Café Point. 2017. Disponível em: < https://www.cafepoint.com.br/colunas/espacoaberto/qualidade-do-cafe-em-mg-e-influenciado-pelas-caracteristicas-locais105919n.aspx > Acesso em: 11 set. 2020.

MESQUITA, C, M de et al. Manual do café: colheita e preparo (Coffea arábica L.). Belo Horizonte: EMATER-MG, 2016. 52 p. il.

MINISTÉRIO DA AGRICULTURA, PECUÁRIA E ABASTECIMENTO; O Café no Brasil. 2018. Disponível em;< http://www.agricultura.gov.br/assuntos/politicaagricola/cafe/cafeicultura-brasileira>. Acesso em: 10 set. 2020.

MUINHOS, R. Fermentação de café. Buena vista café. 08 Junho 2019. Disponível em: <https://buenavistacafe.com.br/blog/tag/fermentacao/> Acesso em: 02 Out. 2020

PEREIRA, L, F, B et al. A influência da fermentação natural na qualidade da bebida do café. Coffe Science. V. 15. Lavras. Editora UFLA. 2020.

PIRES, E, R; CUNHA JÚNIOR, A, da. Efeito da fermentação dos grãos em pós-colheita na qualidade da bebida do café. Patrocínio. Centro Universitário do Cerrado. 2018.

RODRIGUES, G. Z. et al. Avaliação do processo de fermentação controlada do café em diferentes condições de tempo, temperatura e umidade. 2017. Disponível em: <http://www.sbicafe.ufv.br/bitstream/handle/123456789/9424/187_43-

CBPC2017.pdf?sequence=1>. Acesso em: 29 set. 2020.

SANTOS, D, F et al. Efeito do complexo enzimático Inf (cna-cnb) no processo de secagem e a qualidade do café. Coffee Science. V. 15. Lavras. Editora UFLA. 2020.

SILVA, L, F; CORTEZ, J, G. A qualidade do café no Brasil: Histórico e Perspectivas. Cadernos de Ciência \& Tecnologia, Brasília, v.15, n.1, p. 65-91, jan/abril.1998.

SOUZA, A. S.Entenda a fermentação positiva de café Maceração Semi-carbônica ou SproutingProcess. Revista Cafeicultura. 2020.Disponível em $<$ https://revistacafeicultura.com.br/index.php?tipo=ler\&mat=69069\&entenda-afermentacao-positiva-de-cafe-.htmll.> Acesso em: 10 set. 2020.

SPECIALTY COFFEE ASSOCIATION OF AMERICA - SCAA. SCAA protocols cupping specialty coffee. 2015. Disponível em: < https://docplayer.net/20921419-Scaaprotocols-cupping-specialty-coffee.html> Acesso em: 13 set. 2020. 